\title{
Penerapan Model Pembelajaran Project Based Learning dalam Meningkatkan Hasil Belajar Matakuliah Sastra Bandingan Program Studi Pendidikan Bahasa Indonesia FKIP Universitas Bengkulu
}

\author{
Fina Hiasa*1, Supadi ${ }^{2}$ \\ Program Studi Pendidikan Bahasa Indonesia, FKIP, Universitas Bengkulu ${ }^{1,2}$
}

Corresponding email: finahiasa@unib.ac.id*

\begin{abstract}
This study aims to determine how the application of the Project Based Learning (PBL) learning model in improving learning outcomes for Comparative Literature Courses. Through the PBL learning model, students are assigned to work on pocket book project assignments. The subjects of this study were fifth semester students of the Indonesian Language Education Study Program Class A FKIP Bengkulu University who were taking Comparative Literature Courses. The research method uses classroom action research methods. Data collection techniques were carried out through oral tests and questionnaires conducted in the first and second cycles. In the second cycle the expected learning outcomes were achieved. Learning outcomes in the second cycle showed that out of 37 students there were 12 students $(32 \%)$ who got an A. While the rest were students with a B grade of 20 students (54\%). C grades are 5 students (14\%) and $\mathrm{D}$ grades are 0 students $(0 \%)$. These results indicate that an indicator of the successful application of the PBL model by $30 \%$ has been achieved even exceeding the $32 \%$ achievement target. In general it can be concluded that the application of PBL for Comparative Literature Courses in the University of Bengkulu University of Indonesia Language Study Program semester V of class a students of school year 2019/2020 2019/2020 can improve learning outcomes in understanding the concept of comparative literature.
\end{abstract}

Keywords: project based learning, comparative literature

\begin{abstract}
Abstrak
Penelitian ini bertujuan untuk mengetahui bagaimana penerapan model pembelajaran Project Based Learning (PBL) dalam meningkatkan hasil belajar Matakuliah Sastra Bandingan. Melalui model pembelajaran PBL, mahasiswa ditugaskan untuk mengerjakan tugas proyek buku saku. Subjek penelitian ini adalah mahasiswa semester lima Program Studi Pendidikan Bahasa Indonesia Kelas A FKIP Universitas Bengkulu yang sedang mengambil Matakuliah Sastra Bandingan. Metode penelitian menggunakan metode penelitian tindakan kelas. Teknik pengumpulan data dilakukan melalui tes lisan dan kuesioner yang dilakukan pada siklus I dan II. Pada siklus kedua hasil pembelajaran yang diharapkan tercapai. Hasil belajar pada siklus kedua menunjukkan bahwa dari 37 siswa ada 12 mahasiswa (32\%) yang mendapat nilai A. Sedangkan sisanya adalah mahasiswa dengan nilai B sebanyak 20 mahasiswa (54\%). Nilai C
\end{abstract}


sebanyak 5 mahasiswa (14\%) dan nilai D tidak terdapat atau 0 mahasiswa $(0 \%)$. Hasil ini menunjukkan bahwa indikator keberhasilan penerapan model PBL sebesar $30 \%$ telah tercapai bahkan melebihi target pencapaian $32 \%$. Secara umum dapat disimpulkan bahwa penerapan PBL untuk Matakuliah Sastra Bandingan di Program Studi Pendidikan Bahasa Indonesia Universitas Bengkulu semester V siswa kelas A tahun ajaran 2019/2020 dapat meningkatkan hasil belajar dalam memahami konsep sastra bandingan.

Kata kunci: model pembelajaran Project Based Learning, sastra bandingan

\section{PENDAHULUAN}

Sastra Bandingan adalah salah satu matakuliah wajib mahasiswa S-1 Program Studi Pendidikan Bahasa Indonesia (PBI) FKIP Universitas Bengkulu yang memiliki bobot 2 SKS. Capaian pembelajaran matakuliah yang diberikan pada semester $V$ (ganjil) ini adalah mahasiwa memiliki pengetahuan konseptual mengenai teori-teori sastra bandingan dan memiliki kemampuan dalam membandingkan berbagai teks sastra. Materi kuliah Sastra Bandingan dibagi menjadi beberapa bagian yaitu, (1) sejarah perkembangan sastra bandingan dan jenis kajian sastra bandingan, (2) teori-teori sastra untuk kajian sastra bandingan, (3) lingkup sastra bandingan dan klasifikasi sastra bandingan, dan (4) intertekstualitas dalam sastra bandingan (Endraswara, 2011 dan Mayasari, 2016:208).

Matakuliah Sastra Bandingan bertujuan agar mahasiswa memiliki pengetahuan mengenai teori sastra sehingga nantinya mahasiswa sebagai penganalisis karya sastra dapat melakukan kajian bandingan (Allen, 2000). Hal ini menyebabkan pembelajaran cenderung monoton. Untuk membuktikan dugaan tersebut peneliti membagikan angket dengan tujuan mengetahui kondisi awal mahasiswa berkaitan dengan kegiatan pembelajaran. Hasilnya menunjukkan mahasiswa cenderung kurang termotivasi terhadap pembelajaran pada Matakuliah Sastra Bandingan. Hasil inilah yang menjadi dasar bagi peneliti untuk menerapkan model pembelajaran yang membuat kualitas perkuliahan Sastra Bandingan menjadi sesuatu yang bermakna dan menyenangkan bagi para mahasiswa. Bukan hanya itu, pemilihan model pembelajaran yang tepat diharapkan mampu mengembangkan kemampuan kognitif, afektif, dan psikomotor mahasiswa serta keterampilan bernalar terutama dalam melakukan kajian sastra bandingan (Noermanzah dan Maisarah, 2019:199). Model pembelajaran yang tepat juga akan mampu mengarahkan pengajar dalam hal ini dosen dalam melaksanakan pengalaman belajar yang menyenangkan dan inovatif (Noermanzah, 2015; Sartika dan Effendi, 2019).

Penerapan model pembelajaran yang dirasa mampu meningkatkan kualitas pembelajaran Matakuliah Sastra Bandingan adalah model pembelajaran Project Based Learning atau disingkat dengan PBL. Joice (2009:33) dan Leat (2017) menjelaskan bahwa pembelajaran proyek merupakan model pembelajaran yang menggunakan proyek/kegiatan sebagai media. Peserta didik menerima tugas untuk melakukan eksplorasi, penilaian, interpretasi, sintesis, dan informasi untuk menghasilkan berbagai bentuk hasil belajar. Model pembelajaran Project Based Learnig (PBL) ini jika diterapkan memungkinkan kegiatan pembelajaran menjadi semakin berkualitas Waras (2008). Selain itu, mahasiswa pun menjadi lebih aktif dan termotivasi untuk belajar.

Kemudian, model Project Based Learning juga mengajak para mahasiswa untuk lebih mandiri mencari informasi serta mengembangkan kreativitas, melihat dari 
berbagai karakter yang berbeda-beda, dan juga pendidik mengajarkan peserta didik untuk melakukan inovasi atau penciptaan dan melaksanakan eksperimen secara kolaboratif (Sandi, 2018:15). Kelebihan dari model Project Based Learning yaitu peserta didik dituntut untuk lebih banyak melakukan diskusi dengan temannya, dan lebih banyak meluangkan waktu untuk melakukan pencarian atau menemukan hal yang baru sehingga siswa mampu mengembangkan kreativitasnya dengan proyek yang diberikan secara kontekstual.

Penelitian yang relevan terkait dengan penerapan model Project Based Learning yaitu penelitian yang dilakukan oleh Setiana dan Azizah (2017) yang menerapkan Project Based Learning pada pembelajaran menulis puisi. Melalui model pembelajaran PBL mahasiswa mampu menghasilkan puisi dengan diksi yang indah dan larik yang padu pada setiap barisnya. Selain itu, terdapat penelitian yang dilakukan oleh Marlani dan Prawiyogi (2019) yang menerapkan model pembelajaran Project Based Learning (PBL) untuk meningkatkan keterampilan menulis puisi di sekolah dasar. Hasil penelitian ini menunjukkan penerapan model pembelajaran Project Based Learning (PBL) mampu memotivasi siswa dalam menulis puisi sehingga siswa mampu menulis puisi dengan pilihan kata yang baik, indah, dan penuh makna kehidupan.

Perbedaan penelitian yang akan peneliti lakukan dengan penelitian sebelumnya adalah penelitian ini akan mengaplikasikan model pembelajaran Project Based Learning (PBL) pada Matakuliah Sastra Bandingan dengan tujuan untuk peningkatan kualitas pembelajaran agar lebih menyenangkan dan bermakna. Selain itu, tugas proyek mahasiswa adalah menghasilkan produk yaitu pocket book (buku saku) yang menarik untuk merangsang kreativitas mahasiswa yang isinya berkaitan dengan teori-teori sastra untuk kajian sastra bandingan.

Model pembelajaran PBL mengandung aktivitas belajar saintifik yaitu berupa kegiatan bertanya, melakukan pengamatan, penyelidikan, atau percobaan, menalar, serta menjalin hubungan dengan orang lain dalam upaya memperoleh informasi atau data. Oleh karena itu, dengan menerapkan model PBL pada kegiatan pembelajaran sastra bandingan mahasiwa akan terlibat secara aktif baik individu maupun kelompok. Pada penelitian ini mahasiswa secara berlompok akan melakukan kegitan merancang, memecahkan masalah, membuat keputusan, dan melakukan investigasi untuk menyelesaikan tugas proyek berupa membuat buku saku (pocket book) yang berisi teori sastra untuk kajian sastra bandingan.

\section{METODE}

\section{Desain Penelitian}

Penelitian ini menggunakan metode penelitian tindakan kelas (PTK). Desain PTK yang digunakan menggunakan desain model Kemmis dan Mc Taggart dengan empat langkah kegiatan, yaitu: perencanaan, pelaksanaan, pengamatan, dan refleksi.

\section{Populasi dan Sampel}

Populasi penelitian ini adalah seluruh mahasiswa Program Studi (S-1) Pendidikan Bahasa Indonesia FKIP Universitas Bengkulu Tahun Ajaran 2019/2020. Sedangkan sampel dalam penelitian ini adalah mahasiswa semester $\mathrm{V}$ kelas A Program Studi Pendidikan Bahasa Indonesia FKIP UNIB yang sedang mengambil Matakuliah Sastra Bandingan. 


\section{Instrumen Penelitian}

Data dikumpulkan melalui pemberian angket pada mahasiswa yang menjadi sampel penelitian untuk mengetahui situasi awal sebelum penerapan PBL. Dari hasil angket tersebut maka peneliti akan mencoba menerapkan model pembelajaran Project Based Learning (PBL) untuk meningkatkan kualitas pembelajaran pada Matakuliah Sastra Bandingan. Di akhir pembelajaran tim kembali membagikan angket untuk mengetahui ada atau tidaknya peningkatan minat dan keaktifan mahasiswa dalam pembelajaran setelah PBL diterapkan. Selain itu, peneliti juga menggunakan teknik tes berupa tes lisan pada siklus I dan II. Selain angket terdapat lembar pedoman penilaian yang digunakan untuk menilai tugas poyek yaitu membuat pocket book.

\section{Analisis Data}

Teknik analisis data yang digunakan dalam penelitian ini adalah statistik deskriptif, menghitung frekuensi, dan persentase yang disajikan dengan tabel dan grafik. Kategori pada data akan disesuaikan dengan persentase yang ada. Kemudian, hasil tes tugas proyek membuat pocket book berisi teori sastra untuk kajian sastra bandingan disusun menjadi kategori penilaian sebagai berikut.

Tabel 1. Katagori Penilaian Mahasiswa Program Studi PBI FKIP UNIB dalam Membuat Proyek Membuat Buku Saku (Pocket Book) Teori Sastra untuk Kajian Sastra Bandingan

\begin{tabular}{ccl} 
No. & Persentasi & \multicolumn{1}{c}{ Katagori } \\
\hline 1. & $80 \%-100 \%$ & Sangat Baik \\
\hline 2. & $70 \%-79 \%$ & Baik \\
\hline 3. & $60 \%-69 \%$ & Cukup \\
\hline 4. & $45 \%-59 \%$ & Kurang \\
\hline 5. & $0 \%-44 \%$ & Kurang sekali \\
\hline \multicolumn{2}{c}{ (Modifikasi Nurgiyantoro, 2010:363) }
\end{tabular}

\section{Indikator Keberhasilan Penelitian}

Indikator keberhasilan penelitian dilihat dari beberapa aspek yaitu aspek minat dan keaktifan siswa dengan kriteria baik, hasil tes lisan yang menunjukkan kriteria baik, hasil penulisan buku saku dengan kriteria baik, dan hasil siklus I ke siklus II mengalami peningkatan.

\section{HASIL}

Berdasarkan penelitian yang dilaksanakan pada bulan Agustus s.d. Oktober 2019 terhadap 37 orang mahasiswa Program Studi (S-1) Pendidikan Bahasa Indonesia, FKIP Universitas Bengkulu dengan tujuan untuk meningkatkan kualitas pembelajaran mahasiswa semester V kelas A TA 2019/2020 pada Matakuliah Sastra Bandingan menggunakan model pembelajaran Project Based Learning (PBL) diperoleh hasil berikut. 
Penerapan Model Pembelajaran Project Based Learning ...

Tabel 2. Perolehan Nilai Mahasiswa Siklus I dan Siklus II

\begin{tabular}{|c|c|c|c|c|c|c|c|}
\hline \multirow{2}{*}{$\begin{array}{c}\begin{array}{c}\text { Rentang } \\
\text { Nilai }\end{array} \\
90-100\end{array}$} & \multirow{2}{*}{$\begin{array}{c}\text { Huruf } \\
\mathrm{A}\end{array}$} & \multirow{2}{*}{$\begin{array}{l}\text { Deskripsi } \\
\text { Sangat } \\
\text { baik }\end{array}$} & \multirow{2}{*}{$\begin{array}{c}\text { Target Capaian/ } \\
\begin{array}{c}\text { Ketuntasan } \\
\text { Belajar }\end{array} \\
30 \%\end{array}$} & \multicolumn{2}{|c|}{$\begin{array}{c}\text { Perolehan Nilai } \\
\text { Siklus I }\end{array}$} & \multicolumn{2}{|c|}{$\begin{array}{l}\text { Perolehan } \\
\text { Nilai Siklus II }\end{array}$} \\
\hline & & & & 10 & $27 \%$ & 2 & $32 \%$ \\
\hline $80-89$ & $B$ & Baik & $50 \%$ & 20 & $54 \%$ & 0 & $54 \%$ \\
\hline 70-79 & C & $\begin{array}{l}\text { Cukup } \\
\text { baik }\end{array}$ & $20 \%$ & 7 & $19 \%$ & 5 & $14 \%$ \\
\hline $0-69$ & $D$ & $\begin{array}{l}\text { Kurang } \\
\text { baik }\end{array}$ & $0 \%$ & 0 & $0 \%$ & 0 & $0 \%$ \\
\hline \multicolumn{2}{|c|}{ Jumlah } & & 100 & 37 & 100 & 7 & 100 \\
\hline
\end{tabular}

Tabel di atas memperlihatkan hasil pencapaian hasil belajar pada siklus I yaitu sebelum model pembelajaran PBL diterapkan dan siklus II setelah metode pembelajaran PBL diterapkan. Dari tabel di atas tampak terjadi peningkatan hasil belajar pada siklus II yaitu siklus yang menjadi ruang penerapan model pembelajaran PBL. Selanjutnya, akan dijelaskan secara rinci proses pembelajaran yang terjadi di siklus I dan siklus II.

Rencana penelitian tindakan kelas ini akan dilaksanakan dalam dua siklus, dan setiap siklus terdiri dari empat tahap, yaitu (1) tahap perencanaan (planning), (2) tindakan (acting), (3) observasi (observing), dan (4) refleksi (reflecting).

\section{Hasil Pembelajaran pada Siklus 1}

\section{Tahap Perencanaan}

Pada tahap perencanaan dilakukan persiapan perangkat pembelajaran yang diperlukan pada saat proses belajar mengajar, antara lain: (1) menyusun RPS Matakuliah Sastra Bandingan, (2) menyiapkan materi dalam bentuk power point, dan (3) menyiapkan lembar angket evaluasi awal untuk melihat minat siswa dalam kegiatan pembelajaran.

\section{Tahap Pelaksanaan}

Tahap ini merupakan pelaksanaan dari skenario pembelajaran yang telah dibuat pada tahap sebelumnya di dalam kelas, meliputi:

1) Kegiatan awal

a. Dosen mengondisikan kelas (salam, berdoa, mengisi jurnal, mempresensi, dan kehadiran mahasiswa).

b. Dosen menyampaikan tujuan pembelajaran.

c. Pertemuan 1, dosen menyampaikan materi awal tentang hakikat, sejarah, dan jenis sastra bandingan.

d. Selanjutnya di akhir pertemuan, dosen meminta mahasiswa untuk berkelompok dalam membuat makalah yang akan dipresenstasikan di pertemuan selanjutnya.

2) Kegiatan Inti

a. Pertemuan 2, kelompok mahasiswa mempresentasikan sekaligus berdiskusi tentang makalah yang materinya berupa konsep, tujuan, dan ruang lingkup sastra bandingan. 
e. Pertemuan 3, setelah semua kelompok presenstasi, dosen meminta mahasiswa mengisi angket berdasarkan pembelajaran yang telah dilakukan sebelumnya untuk mengetahui situasi awal kegiatan pembelajaran.

f. Pertemuan 4, dosen menganalisis hasil angket lalu merencanakan penerapan model pembelajaran untuk meningkatkan hasil pembelajaran.

2) Kegiatan akhir

Berdasarkan hasil pra tindakan, dosen menjelaskan rencana mengenai pelaksanaan model pembelajaran dalam pembelajaran sastra bandingan

\section{Observasi dan Refleksi Siklus I}

Berdasarkan data nilai mahasiswa pada siklus 1 menunjukkan bahwa hasil pembelajaran sebelum metode PBL diterapkan belum dapat memenuhi target capaian yang diharapkan dalam perkuliahan Sastra Bandingan. Pernyataan tersebut didukung oleh hasil capaian dari tes lisan bahwa dari 37 mahasiswa hanya ada 10 mahasiswa $(27 \%)$ yang mendapat nilai A. Sedangkan sisanya yaitu mahasiswa dengan perolehan nilai B sebanyak 20 orang (54\%). Nilai C sebanyak 7 orang (19\%) dan nilai $D$ sebanyak 0 orang $(0 \%)$. Target capaian atau ketuntasan belajar yaitu $A$ sebesar $30 \%$, B sebesar $50 \%$, C sebesar $20 \%$, dan D $0 \%$. Hasil pembelajaran pada siklus I menggunakan metode konvesional memperlihatkan bahwa ketuntasan belajar atau target capaian belum dapat tercapai. Hal ini juga sejalan dengan situasi awal minat dan motivasi mahasiswa yang tergambarkan melalui diagram di bawah ini.

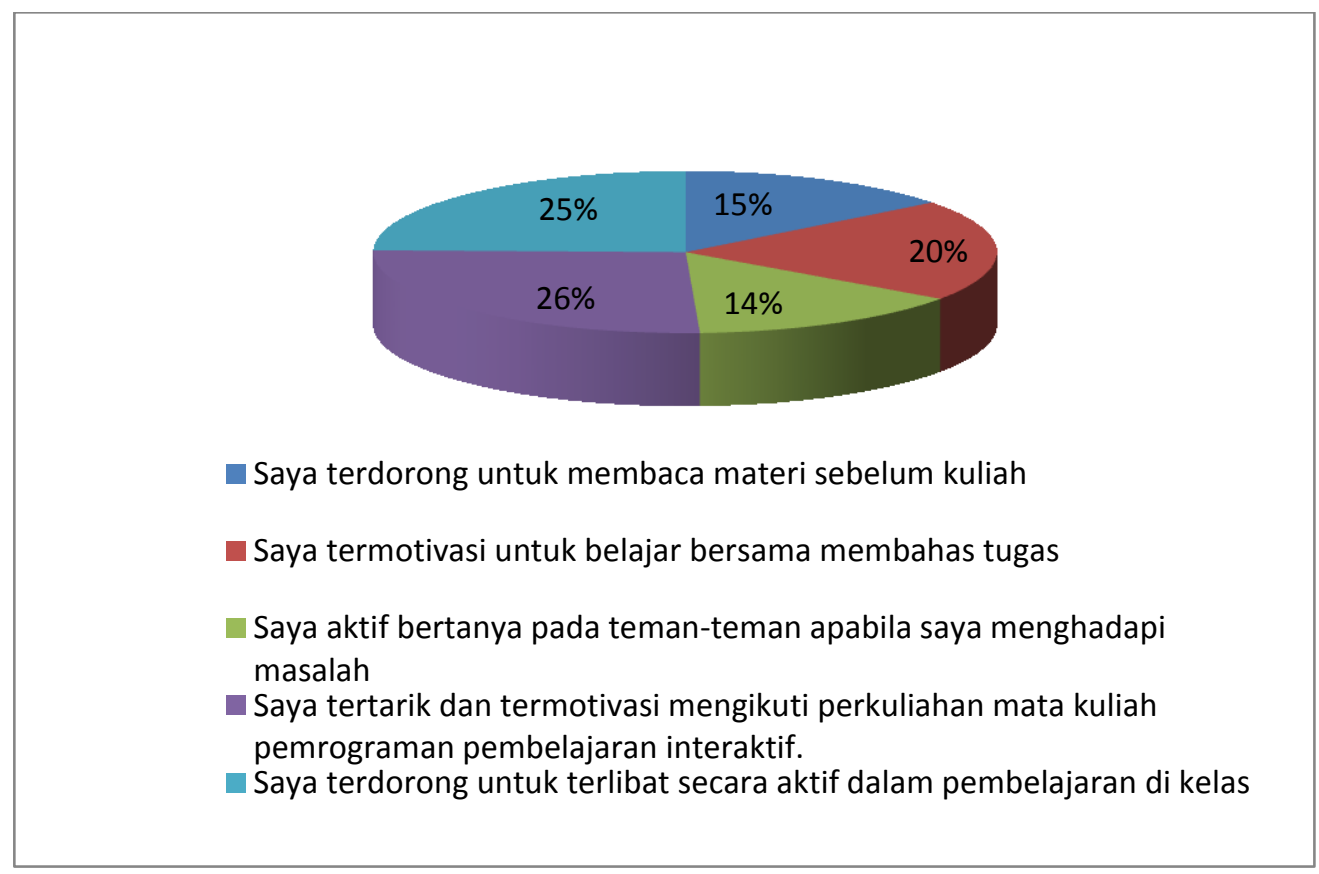

Gambar 1. Persentase Minat dan Keaktifan Mahasiswa pada Situasi Awal Pembelajaran Sebelum PBL Diterapkan

Gambar diagram di atas merupakan hasil dari penyebaran angket yang dilakukan oleh tim peneliti setelah pembelajaran pada siklus I. Hasilnya adalah dari 37 orang mahasiswa hanya $15 \%$ yang terdorong untuk membaca materi sebelum kuliah. Sebanyak $20 \%$ dari 37 orang mahasiswa termotivasi untuk belajar bersama 
membahas tugas. Selanjutnya, hanya $14 \%$ yang tertarik bertanya pada teman-teman apabila saya menghadapi masalah. Lalu sebanyak $26 \%$ dan $25 \%$ tertarik dan termotivasi mengikuti perkuliahan mata kuliah pemrograman pembelajaran interaktif, dan juga termotivasi untuk mengerjakan tugas secara sungguh sungguh. Hasil ini menunjukkan bahwa minat dan motivasi mahasiswa dalam pembelajaran masih cukup rendah. Oleh karena itu, tim peneliti akan menerapkan metode PBL untuk meningkatkan hasil belajar mahasiswa. Metode PBL ini akan dilakukan di siklus II yang harapannya dapat meningkatkan hasil belajar.

\section{Hasil Pembelajaran pada Siklus II}

\section{Tahap Perencanaan}

Pada tahap perencanaan dilakukan persiapan perangkat pembelajaran yang diperlukan pada saat proses belajar mengajar, antara lain: (1) menyusun RPS Matakuliah Sastra Bandingan, (2) menyiapkan materi dalam bentuk power point, (3) menyiapkan lembar pedoman penilaian dalam pelaksanaan model pembelajaran Project Based Learning (PBL), dan (4) menyiapkan angket untuk evaluasi akhir untuk menilai ada atau tidaknya peningkatan pembelajaran setelah PBL diterapkan.

\section{Tahap Pelaksanaan}

Tahap ini merupakan pelaksanaan dari skenario pembelajaran yang telah dibuat pada tahap sebelumnya di dalam kelas, meliputi:

1) Kegiatan awal
a. Dosen mengondisikan kelas (salam, berdoa, mengisi jurnal, mempresensi dan kehadiran mahasiswa).
b. Pertemuan 5, dosen menyampaikan refleksi dari pelaksanaan model pembelajaran konvensional sebelumnya (siklus I) dan menjelaskan model pembelajaran yang akan diterapkan selanjutnya yaitu Project Based Learning (PBL) pada siklus II yang bertujuan agar terjadi peningkatan proses belajar.

2) Kegiatan Inti

a. Pertemuan 6, dosen dan mahasiswa mengimplementasikan model pembelajaran PBL dengan tugas proyek yang diberikan oleh dosen yaitu membuat buku saku (pocket book) yang isinya teori-teori sastra untuk menganalisis menggunakan metode sastra bandingan yang tujuannya untuk menemukan interteks sebuah karya sastra.

b. Pertemuan 7, mahasiswa memperesentasikan dalam bentuk power point dan membedah tugas proyeknya yaitu berbentuk pocket book.

c. Pertemuan 8 , dosen mengadakan tes lisan berkaitan dengan isi pocket book yang telah dibuat dan membagikan angket untuk mengetahui ada atau tidaknya peningkatan pembelajaran setelah PBL diterapkan.

3) Kegiatan akhir
a. Mahasiswa membuat simpulan mengenai proses pembelajaran yang telah diikutinya.
b. Dosen memberikan penguatan terhadap simpulan yang telah disampaikan mahasiswa.

\section{Observasi dan Refleksi Siklus II}

Pada siklus II terjadi peningkatan hasil belajar, pernyataan ini didukung oleh data hasil tes yang dilakukan oleh tim peneliti menunjukkan bahwa ada peningkatan 
yang terjadi yaitu dari 37 mahasiswa ada 12 mahasiswa (32\%) yang mendapat nilai A. Sedangkan sisanya yaitu mahasiswa dengan perolehan nilai B sebanyak 20 orang (54\%). Nilai C sebanyak 5 orang (14\%) dan nilai D sebanyak 0 orang (0\%). Hasil pembelajaran pada siklus II menggunakan metode pembelajaran PBL dengan memberikan tugas proyek berupa membuat pocket book yang akan digunakan untuk menganalisis menggunakan metode sastra bandingan memperlihatkan bahwa ketuntasan belajar atau target capaian dapat tercapai bahkan melebihi target capaian yaitu sebesar $32 \%$. Hal ini juga sejalan dengan situasi akhir minat dan motivasi mahasiswa yang tergambarkan melalui diagram di bawah ini.

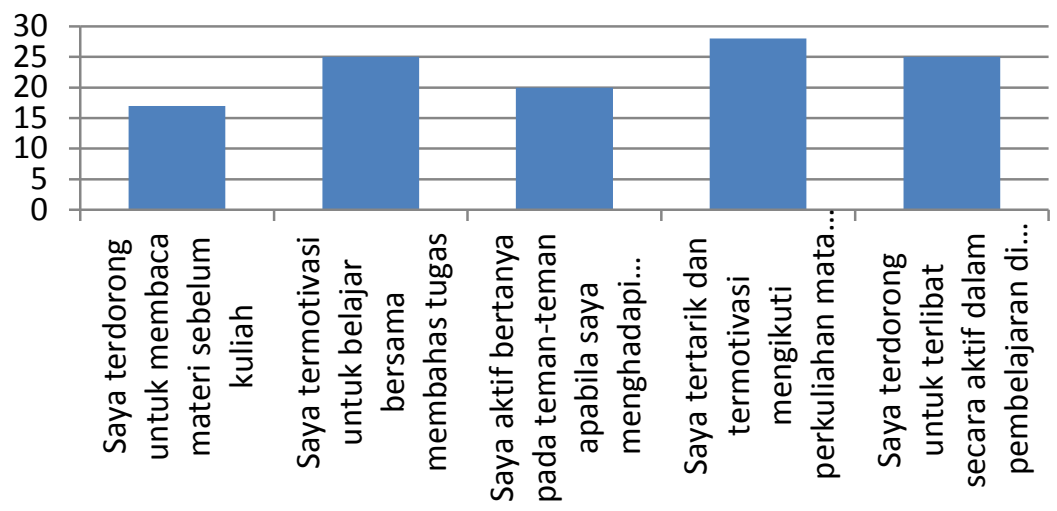

Gambar 2. Persentase Minat dan Keaktifan Mahasiswa pada Situasi Akhir Pembelajaran

Diagram batang di atas merupakan hasil dari penyebaran angket yang dilakukan oleh tim peneliti setelah pembelajaran pada siklus II (setelah PBL diterapkan). Hasilnya adalah dari 37 orang mahasiswa 17 mahasiswa yang terdorong untuk membaca materi sebelum kuliah. Sebanyak 25 dari 37 orang mahasiswa termotivasi untuk belajar bersama membahas tugas. Selanjutnya, hanya 20 orang yang tertarik bertanya pada teman-teman apabila saya menghadapi masalah. Lalu sebanyak 28 dan 25 orang tertarik dan termotivasi mengikuti perkuliahan matakuliah pemrograman pembelajaran interaktif, dan juga termotivasi untuk mengerjakan tugas secara sungguh sungguh. Hasil ini menunjukkan bahwa minat dan motivasi mahasiswa dalam pembelajaran meningkat setelah menerapkan metode PBL.

\section{PEMBAHASAN}

Penerapan model pembelajaran Project Based Learning (PBL) pada Matakuliah Sastra Bandingan Program Studi (S-1) Pendidikan Bahasa Indonesia FKIP Universitas Bengkulu Semester V Kelas A Tahun Ajaran 2019/2020 dapat meningkatkan hasil belajar mahasiswa terutama dalam memahami teori sastra bandingan. Ketercapaian target persentase ketuntasan terjadi setelah penerapan PBL pada siklus II. Hal ini menunjukkan bahwa model Project Based Learnig benarbenar mampu memberikan motivasi kepada siswa untuk semangat belajar Matakuliah Sastra Bandingan. Hal ini sesuai dengan pendapat Joice (2009:33) bahwa pembelajaran proyek merupakan model pembelajaran yang menggunakan proyek/kegiatan sebagai media, yang dalam hal ini menggunakan proyek buku saku. Peserta didik menerima tugas buku saku untuk melakukan eksplorasi, penilaian, interpretasi, sintesis, dan informasi untuk menghasilkan berbagai bentuk hasil belajar 
yang berkualiatas yaitu pemahaman terhadap teori tentang sastra bandingan mealui proyek buku saku. Selain itu, prosedur model PBL juga mengajak mahasiswa untuk lebih banyak melakukan diskusi dengan temannya, dan lebih banyak meluangkan waktu untuk melakukan pencarian atau menemukan hal yang baru sehingga siswa bekerja sebagai individu dan bekerja dalam kelompok mampu mengembangkan kreativitasnya dengan proyek dan diskusi hasil proyek yang diberikan secara kontekstual (Sandi, 2018:15).

Hasil pembelajaran Matakuliah Sastra Bandingan dengan menggunakan model PBL pada siklus I menunjukan dari 37 mahasiswa hanya ada 10 mahasiswa $(27 \%)$ yang mendapat nilai A. Sedangkan sisanya yaitu mahasiswa dengan perolehan nilai B sebanyak 20 orang (54\%). Nilai C sebanyak 7 orang (19\%) dan nilai $D$ sebanyak 0 orang $(0 \%)$. Target capaian atau ketuntasan belajar yaitu $A$ sebesar $30 \%$, B sebesar $50 \%$, C sebesar $20 \%$, dan D $0 \%$. Hasil pembelajaran pada siklus I memperlihatkan bahwa indikator keberhasilan dalam penerapan PBL sebanyak $30 \%$ belum tercapai, oleh karena itu perlu dilanjutkan ke siklus II.

Hasil pembelajaran pada siklus II menunjukan dari 37 mahasiswa ada 12 mahasiswa $(32 \%)$ yang mendapat nilai A. Sedangkan sisanya yaitu mahasiswa dengan perolehan nilai B sebanyak 20 orang (54\%). Nilai C sebanyak 5 orang $(14 \%)$ dan nilai $D$ sebanyak 0 orang $(0 \%)$. Hasil pembelajaran pada siklus II menggunakan metode pembelajaran PBL dengan memberikan tugas proyek berupa membuat pocket book yang akan digunakan untuk menganalisis menggunakan metode sastra bandingan memperlihatkan bahwa ketuntasan belajar atau target capaian dapat tercapai. Hasil ini memperlihatkan bahwa indikator keberhasilan dalam penerapan PBL sebanyak $30 \%$ telah tercapai bahkan melebihi target capaian yaitu sebesar $32 \%$. Model pembelajaran PBL dianggap sebagai suatu strategi efektif untuk meningkatkan hasil belajar mahasiswa. Mahasiwa secara individu dan kelompok dapat meningkatkan kemampuan akademiknya. Selain itu, aspek sosial yang menjadikan pembelajaran tidak hanya bermakna, tetapi juga menyenangkan dapat tercapai. Secara umum dapat disimpulkan bahwa penerapan PBL untuk Matakuliah Sastra Bandingan pada mahasiswa Program Studi (S-1) Pendidikan Bahasa Indonesia FKIP Universitas Bengkulu Semester V Kelas A Tahun Ajaran 2019/2020 dapat meningkatkan hasil belajar dalam memahami konsep sastra bandingan.

Keberhasilan penerapan model Project Based Learning juga dipengaruhi oleh pemberian penghargaan dosen kepada mahasiswa dalam setiap aktivitas pembelajaran, terutama pemberian penghargaan dalam bentuk lisan dengan ucapan selamat, benar sekali, dan luar biasa. Selain itu, pemberian penghargaan dalam bentuk kinesik yaitu tepuk tangan dan ajungan jempol semakin membuat mahasiswa semakin kreatif, mampu bekerja sama, mampu berkolaborasi dalam tim, dan mampu memberikan pemikiran kritis dalam kegiatan diskusi. Hal ini sesuai dengan tuntutan pembelajaran di era milenial bahwa mahasiswa harus mampu memiliki kemampun berpikir kritis, kreatif, bekerja sama, komunikatif, dan mahir komputerisasi (Mustikawati, 2019:99; Noermanzah dan Friantary, 2019:6631; Sulaeman dan Ariyana, 2018:207-208). Penghargaan dalam bentuk lisan dan kinesik ini juga menjadikan siswa termotivasi untuk belajar terutama dalam membuat buku saku tentang sastra bandingan dan ketika kegiatan diskusi. Kemudian, pemberian penguatan oleh dosen terhadap materi juga sangat penting terutama ketika kegiatan ekplorasi dan elaborasi sehingga ketika kegiatan tes siswa memiliki pemahaman yang baik dalam menjawab soal yang diberikan tentang teori sastra bandingan. 


\section{KESIMPULAN DAN SARAN}

Dari hasil penelitian yang telah dilakukan, dapat disimpulkan bahwa: (1) penerapan model pembelajaran Project Based Learning (PBL) untuk Matakuliah Sastra Bandingan pada mahasiswa Program Studi (S-1) Pendidikan Bahasa Indonesia FKIP Universitas Bengkulu Semester V Kelas A Tahun Ajaran 2019/2020 dapat meningkatkan hasil belajar mahasiswa dalam memahami konsep sastra bandingan. Ketuntasan belajar dapat diperoleh di siklus II dari dua siklus yang direncanakan. Kemudian, (2) peningkatan hasil belajar ini menunjukkan bahwa model Project Based Learning (PBL) dianggap sebagai suatu suatu strategi efektif untuk meningkatkan hasil belajar mahasiswa. Mahasiwa secara individu dan kelompok dapat meningkatkan kemampuan akademiknya. Selain itu, aspek sosial yang menjadikan pembelajaran tidak hanya bermakna, tetapi juga menyenangkan dapat tercapai. Untuk penelitian selanjutnya, diharapkan dalam menerapkan model pembelajaran Project Based Learning (PBL) dapat mengaplikasikan pada matakuliah yang berbeda dengan menggunakan variasi proyek yang diberikan kepada mahasiswa.

\section{DAFTAR PUSTAKA}

Allen, G. (2000). Intertextuality. London: Routiedge.

Endraswara, S. (2011). Sastra Bandingan: Pendekatan dan Teori Pengkajian. Yogyakarta: Lumbung IImu.

Leat, D. (2017). Enquiry and Project Based Learning. Enquiry and Project Based Learning, 85-107. doi:10.4324/9781315763309-4

Marlani, L., \& Prawiyogi, A. G. (2019). Penerapan Model Pembelajaran Project Based Learning untuk Meningkatkan Keterampilan Menulis Puisi di Sekolah Dasar. Al-Aulad: Journal of Islamic Primary Education, 2(1). doi:10.15575/alaulad.v2i1.4427

Mayasari, G. H. (2016). Meneropong Teori Sastra Bandingan pada Buku Metodologi Penelitian Sastra Bandingan. METASASTRA: Jurnal Penelitian Sastra, 4(2), 208. doi:10.26610/metasastra.2011.v4i2.208-2011

Mustikawati, F. E. (2019). Fungsi Aplikasi Kahoot sebagai Media Pembelajaran Bahasa Indonesia. Prosiding Seminar Nasional Bulan Bahasa (Semiba), https://ejournal.unib.ac.id/index.php/semiba/article/view/10281/5162

Noermanzah \& Friantary, H. (2019). Development of Competency-Based Poetry Learning Materials for Class $X$ High Schools. International Journal of Recent Technology and Engineering, 8(4), 6631.

Noermanzah, N. \& Maisarah, I. (2019). Pemilihan Strategi Pembelajaran Bahasa yang Efektif dan Tepat pada Pendidikan Dasar sebagai Wujud Implementasi Kurikulum 2013. Prosiding Seminar Nasional Bulan Bahasa (Semiba), https://ejournal.unib.ac.id/index.php/semiba/article/view/10299 
Noermanzah, N. (2015). Peran Dosen Bahasa dan Sastra Indonesia dalam Mempertahankan Bahasa Indonesia sebagai Alat Pemersatu Negara Kesatuan Republik Indonesia pada Era Globalisasi. Prosiding Seminar Nasional Bulan Bahasa 2015. Unit Penerbitan FKIP Universitas Bengkulu, p. 274. http://repository.unib.ac.id/11133/

Nurgiyantoro, B. (2010). Penilaian Pembelajaran Bahasa. Yogyakarta: BPFE.

Sandi, N. V. (2018). Penerapan Model Project Based Learning melalui Pembelajaran Drama dalam Mengembangkan Kreativitas Mahasiswa. Jurnal Pendidikan dan Kajian Seni, 3(1). doi:10.30870/jpks.v3i1.4064

Sartika, W., \& Effendi, M. S. (2019). Pengaruh Model Pembelajaran PQ4R (Preview, Question, Read, Reflect, Recite, and Review) terhadap Kemampuan Menganalisis Unsur Naskah Drama Siswa Kelas XI SMA Negeri 3 Lubuklinggau. Diksa: Pendidikan Bahasa dan Sastra Indonesia, 5(2), 86-93. doi:10.33369/diksa.v5i2.9987

Sulaeman, A., \& Ariyana, A. (2018). Pengaruh Penggunaan Model Pembelajaran Examples Non-Examples terhadap Hasil Belajar Menulis Teks Berita pada Siswa Kelas VIII SMPN 14 Kota Tangerang. Silampari Bisa: Jurnal Penelitian Pendidikan Bahasa Indonesia, Daerah, dan Asing, 1(2), 17-27. doi:10.31540/silamparibisa.v1i2.201

Waras, K. (2008). Project-Based Learning: Pendekatan Pembelajaran Inovatif. Makalah. Disampaikan dalam Pelatihan Penyusunan Bahan Ajar Guru SMP dan SMA Kota Tarakan, 31 Oktober s.d. 2 November 2008. Universitas Negeri Malang. Diakses pada tanggal 4 Desember 2013 di http://wekasyah88.blogspot.com/2012/01/project-based-learning-pbl.html 